\title{
Gerakan Earth Hour Tangerang Dalam Perspektif Politik Lingkungan
}

Ilham Rasyid

Ilmu Pemerintahan, FISIP Universitas Sultan Aeng Tirtayasa irasyid09@gmail.com

\section{Jessica Roma Felixiani Keviola}

Ilmu Pemerintahan, FISIP Universitas Sultan Aeng Tirtayasa jessicafel13@gmail.com

\section{E-ISSN (2721-0642)}

\section{Recieved:}

May 212020

Revised:

June 172020

Accepted:

August 132020

Doi Number

10.37950/ijd.v2i2.42

\begin{abstract}
In this scientific work, the writer will focus on discussing social movements based on the environment carried out by Non-profit Organizations namely Tangerang Earth Hour can be said as a forum or community that not only stands because of one goal of "Electricity Savings" but more than that now, this community aims to make the habit or culture of environmental care a lifestyle that should have been applied by all levels of society and must be sustainable. In this study, researchers used qualitative research methods. The conclusion of this research is, the Earth Hour Tangerang movement is able to become a movement that has a good impact on the Tangerang Raya region. With a strategic approach and able to embrace the government, corporate, community, and also other communities, Earth Hour Tangerang has been able to raise the urgency of the importance of environmental care and also environmental issues in the Tangerang Raya region.
\end{abstract}

Keywords: earth hour tangerang, social movements, enviroment politics

\begin{abstract}
Abstrak
Pada karya ilmiah ini penulis akan fokus membahas tentang gerakan sosial yang berbasis lingkungan yang dilakukan oleh organisasi non-profit yaitu Earth Hour
\end{abstract}


Tangerang. Earth Hour dapat dikatan sebagai wadah atau komunitas yang bukan hanya berdiri karena satu tujuan "Penghematan Listrik" akan tetapi lebih dari itu sekarang, komunitas ini bertujuan menjadikan kebiasaan atau budaya peduli lingkungan menjadi suatu gaya hidup yang harusnya telah diaplikasikan oleh seluruh lapisan masyarakat dan harus berkelanjutan. Pada penelitian ini, metode yang digunakan ialah penelitian kualitatif. Kesimpulan dari penelitian ini adalah gerakan Earth Hour Tangerang mampu menjadi sebuah gerakan yang memiliki pengaruh yang baik bagi wilayah Tangerang Raya dalam perspektif politik lingkungan. Dengan pendekatan yang strategis dan mampu merangkul pemerintah, korporat, masyarakat, dan juga komunitas lainnya, Earth Hour Tangerang sudah mampu mengangkat urgensi pentingnya pemeliharaan lingkungan dan juga isu lingkungan pada wilayah Tangerang Raya.

Kata Kunci: eart hour tangerang, gerakan sosial, politik lingkungan

\section{Pendahuluan}

Gerakan sosial hadir karena keresahan atau kekecewaan terhadap kebijakan atau isu tertentu yang dapat merugikan suatu kelompok atau populasi. Salah satunya adalah gerakan yang membawa isu lingkungan baik di tingkat lokal maupun internasional. Keperhatian tersebut timbul karena adanya dampak kerusakan lingkungan cukup parah. Dari sekian banyak isu lingkungan yang dibawa salah satunya adalah penghematan energi.

Energi merupakan salah satu kebutuhan penting dalam kehidupan manusia. Enegeri membuat manusia mampu beraktifitas untuk sehari hari.Indonesia menjadi salah satu negara yang menggunakan energi terbanyak di dunia karena jumlah penduduknya yang memang cukup banyak. Menurut Badan Pusat Statistik, diprediksikan sampai tahun 2045, penduduk Indonesia diperkirakan akan mencapai 319 juta jiwa. Dalam kegiatan sehari hari yang cukup memakan waktu, kegiatan kegiatan manusia biasanya memakan cukup banyal engeri dkarenakan banyaknya alat alat rumah tangga, perkantoran, dan lain sebagainya menggunakan energi dengan balasan mereka akan mendapatkan kemudahan dalam setiap pekerjaannya.

Gerakan sosial yang membahas isu lingkungan hidup sekarang sudah menjadi diskusi bagi dunia internasional, bukan saja menjadi pembahasan lokal maupun nasional lagi. Penggunaan bahan bakar fosil, penebangan hutan, dan pemborosan energi merupakan faktor yang menyebabkan bumi memiliki kondisi yang cukup prihatin. Permasalahan tersebut disebabkan karena sudah terjadi kerusakan di bumi dan lingkungan sekitar kita contohnya saja adanya pemanasan globa, efek rumah kaca, perubahan iklim secara drastis, dan lainnya. Pemikiran ekologis membahas kepentingan alam itu sendiri, bukan hanya kepentingan kemanusiaan di alam. Teori hijau menangkap orientasi ini dari segi nilai dan agensi politik apa yang harus dinilai, 
oleh siapa dan bagaimana cara mendapatkannya. Teori hijau termasuk dalam tradisi teori kritis, dalam arti bahwa masalah lingkungan menimbulkan pertanyaan tentang hubungan antara dan di antara kita dan orang lain dalam konteks masyarakat dan pengambilan keputusan kolektif. Pada gilirannya, ini selalu menimbulkan pertanyaan tentang dimana batas-batas komunitas politik. Untuk masalah lingkungan, yang melampaui batas, pertanyaan-pertanyaan ini mengambil bentuk bertanya pada tingkat komunitas politik mana kita harus mencari solusinya. Bagi ahli teori hijau, jawabannya ditemukan dalam ide-ide alternatif tentang asosiasi politik berdasarkan hubungan ekologis kita.

Pada karya ilmiah ini peneliti akan fokus dengan mengkaji gerakan yang sudah dilakukan oleh organisasi non-profit ialah Earth Hour Tangerang. Pada tahun 2004, WWF Australia telah merencang atau menyusun idea agar melakukan penghematan energi yang memiliki tujuan untuk meminimalisir dampak pemanasan global. Kemudian terealisasikan ide tersebut menjadi suatu bentuk kegiatan yang dinamai Earth Hour. Setiap tahunnya, pelaksanaan selalu dilaksanakan pada hari sabtu di akhir bulan Maret. Di tahun 2007, sekitar dua juta masyarakat Sydney dan 2100 perusahaan ikut berpartsipasi dalam kegiatan tersebut. Earth Hour yang digagas WWF Australia mengajak kerjasama Leo Bunet dan Fairfax media. Pergerakan massa yang bernama Earth Hour telah mengglobal karena dalam setahun atau tepatnya pada tahun 2008 ada 371 kota di 75 negara yang turut berpartisipasi.

Sementara itu, sampai saat ini WWF Indonesia terus berupaya mengembangkan dan memperluas jaringan kampanye Earth Hour, terutama pada kota-kota besar seperti Surabaya, Medan, Jakarta, Makassar, Kalimantan, Papua dan salah satunya Tangerang. Kota-kota besar misalnya seperti Tangerang dan Jakarta adalah pengguna sumber daya listrik dengan jumlah cukup besar. Selanjutnya Earth Hour berkampanye melalui online yang sebelumnya telah dilaksanakan kampanye secara langsung. Kampanye online ini berhasila menjadi yang terbesar di dunia, setelah itu negara Brazil dan Amerika mengikuti. Selanjutnya di tahun 2015, sekitar 40 kota di Indonesia ikut andil dalam peringatan dan mendapat dukungan dari berbagai tokoh publik baik ditingkat lokal maupun nasional.

Pada pelaksanaanya, organisasi atau komunitas ini menggandeng seluruh masyarakat, mulai dari, pelajar, rumah tangga, media massa, sesama komunitas, pemerintahan sampai perusahaan atau korporasi untuk bersama-sama bersinergi melakukan kegiatan ini. Gerakan Earth Hour tidak sekedar simbolis semata, melainkan menjadikan aksi guna merubah lingkungan di bumi kita ini secara bersama agar tetap hijau dan lestari. Ketika selebrasi, bukan hanya switch off akan tetapi yang diharapkan adalah perubahan yang terwujud di sektor lain seperti penggunaan plastik, penggunaan transportasi publik, dan daur ulang sampah sehingga dapat menerapkan kebiasaan menjaga lingkungan.

Saat ini, Earth Hour dapat dikatan sebagai wadah atau komunitas yang bukan hanya berdiri karena satu tujuan "Penghematan Listrik" akan tetapi lebih dari itu sekarang, komunitas ini bertujuan menjadikan kebiasaan atau budaya peduli lingkungan menjadi suatu gaya hidup yang harusnya telah diaplikasikan oleh seluruh 
lapisan masyarakat dan harus berkelanjutan. Misalnya kegiatan yang telah dilakukan Earth Hour yaitu ketika memperingati hari penting lingkungan seperti Hari bumi yang diperingati dengan aksi menanam pohon mangrove ditepi pantai atau menanam pohon di perkotaan.

Gerakan ini memiliki fokus utama adalah mengedukasi masyarakat seperti mengubah gaya hidup agar dapat peduli lingkungan atau menanamkan pemahaman akan pentingya menjaga lingkungan itu sendiri. Contoh kegiatan nyata lainnya yaitu aksi EH Goes to School. Komunitas ini mendatangi beberapa sekolah untuk mengenalkan dan mengedukasi bagaimana pentingya peduli lingkunga. Setelah itu, dilanjutkan dengan aksi rampok sampah secara langsung dipusat-pusat perbelanjaan yang terlihat jelas banyak menggunakan plastik sekali pakai, lalu Earth Hour menukarnya dengan membagikan tote bag guna mengganti kantong plastik sekali pakai tersebut.

Peneliti akan menulis tentang studi kasus gerakan Earth Hour Tangerang, khususnya komunitas ini hendak memberikan edukasi bahwa tidak cukup dengan mematikan listrik satu jam setiap tahun jika ingin melakukan perubahan terhadap lingkungan, akan tetapi peduli lingkungan harus dilakukan setiap hari dan diikuti oleh banyak pihak. Earth Hour bukan cuma peristiwa perayaan saja, akan tetapi momen atau kesan terhadap diri sendiri untuk melakukan perubahan sederhana dan ketika dimasa yang akan datang bisa memberikan dampak yang besar dan menjadikan gaya hidup kita. Saat menggalang dukungan untuk kampanye hemat energi, Earth Hour Tangerang dari tahun 2012 hingga sekarang melakukan pendekatan melalui pemerintahan, korporasi, masyarakat, media dan komunitas lain. Pendekatan ini dilakukan guna salah satu cara agar dukungan secara penuh dalam setiap agenda atau aksi yang dilakukan. Dukungan tersebut menjadi modal dasar Earth Hour Tangerang sebagai environment movement change untuk Tangerang Raya.

Dari ketiga wilaya Tangerang Raya, ketiganya saat ini belum jelas memiliki peraturan tentang isu peduli lingkungan. Peraturan atau kebijakan yang selama ini dibuat didominasi hasil penanganan yang kasuistik, tidak secara holistik atau serium dalam membahas kasus. Seperti, ketik ada permasalahan tentang pengelolaan sampah, maka pemerintah kabupaten/kota biasanya baru akan mengeluarkan peraturan bagiamana menanggulangi sampah. Artinya pemerintah lewar peraturan daerah (perda) yang dikeluarkan belum serius terhadap isu lingkungan yang sebenarnya bukan hanya masalah yang sudah terjadi, namun bagaimana tindakan preventif terhadap isu lingkungan itu sendiri.

Maka dari itu, terlihat bahwa kurangnya inisiatif pemerintah untuk membuat regulasi yang berbentuk penanganan preventif terkait isu lingkungan, bisa dikatakan kedepannya permasalahan yang ditimbulkan akan semakin menumpuk atau banyak. Harusnya ada perubahan sistem ataupun pola berfikir dalam pemerintahan yang harus mengambil tindakan preventif dan edukatif terhadap masyarakat, dengan seperti itu merupakan suatu tindakan yang bertujuan mewujudkan lingkungan yang berkelanjutan.Berdasarkan latar diatas, pertanyaan yang sederhana apakah Gerakan 
Earth Hour Tangerang dalam perspektif politik lingkungan dapat memperjuangkan kepentingan isu lingkungan sebagai sebuah gereakan atau aksi sosial baru.

\section{Kerangka Teori}

Kerangaka teori pada sebuah penelitian adalah uraian mengenai teori dan hasil penelitian yang relevan terhadap variabel yang akan ditelti. Maka dari itu penliti menjelaskan teori yang digunakan sebagai acuan dalam melakukan penelitian. Dalam penelitian ini peneliti mengkaji beberapa teori diantaranya sebagai berikut:

\section{Gerakan Sosial}

Gerakan sosial baru adalah gerakan yang memiliki pembaharuan dari gerakan sosial lama atau menambahkan inovasi dari gerakan lama. Gerakan sosial baru ini ditandai dengan banyaknya gerakan hak - hak sipil di Amerika Serikat pada tahun 1955 - 1968 (Suharko, 2006).

Isu isu yang diangkat semakin meluas dan memiliki cakupan yang luas dibandingkan dengan gerakan sosial lama. Isu-isu yang diangkat, merupakan isu-isu terkait gaya hidup manusia dan pemikiran yang lebih luas di banding pemikiran Marx di era gerakan sosial lama. Green politics, Feminism, gerakan menolak pemerintahan yang otoriter di Eropa dan Amerika, dan sebagainya menjadi isu - isu dari gerakan sosial baru. Gerakan sosial baru memiliki ciri khas dimana gerakan ini mementingkan perubahan gaya hidup manusia. Gerakan sosial baru tidak mementingkan hal hal yang berbau materialistik.

Dalam bahasa Indonesia Civil Society atau gerakan sosial diterjamahkan dalam tiga cara, diantaranya masyarakt warga, masyarakat sipil, dan masyarakat madani. Pengertian civil society sebagai masyarakat sipil dipandang oleh berbagai kalangan kurang tepat. Karena dalam dunia akademik Indonesia dan kesehariannya, konsep sipil selalu dihubungkan dengan konsep militer. Maka pemahaman konsep tersebut akan disalahpahami maksudnya dari konsep civil society tersebut.

Selanjutnya mengenai masyarakat warga/kewargaan adalah terjemahan yang mengarah pada kata civic. Pengertian tersebut mengingatkan pada pendidikan kewarganegaraan yang telah diajarkan sebelum tahun 1970. Akhirnya berakibat memberikan kesan masyarakat warga ialah masyarakat yang menjadi warga negara yang baik. Civil society adalah konsep yang telah lahir dari pandangan terdapat hubungan antar masyarakat dan negara yang mengalami evolusi dari jaman ke jaman. Terdapat tiga konsep kekuasaan yang mengatur kehidupan manusia, yaitu state (negara), market (pasar), dan civil society.

Civil society didefinisikan secara teoritis ialah masyarakat yang bebas dari ketergantungan oleh negara dan pasar, percaya diri, swawsembada, sukarela dan taat terhadap norma dan nilai yang berlaku secara tertulis maupun tidak tertulis. Terbebas dari ketergantungan terhadap negara dan pasar diartikan sebagai bentuk kebebasan dari pada masyarakat itu sendiri untuk beraktivitas kemasyarakatan misalnya sosial, politik, budaya dan agama. Tanpa adanya tekanan dari negara dan pasar. Tekanan oleh negara terhadap masyarakat diperbolehkan akan tetapi jika 
terjadi ketidakadilan dalam kehidupan bernegara dan bermasyarakat, aturan tersebut dilanggar atau undang-undang yang berlaku tidak ditegakkan sebagai mana mestinya.

Kemudian civil society, kelompok atau individu memiliki keprecayaan diri. Yang dimaskud dengan percaya diri adalah suatu kondisi dimana terdapat potensi dan kapasitas yang telah dimiliki dan dipandang mampu dalam menyelesaikan permasalahan yang akan dihadapi. Sedangkan swasembada merupakan kemampuana untuk melakukan suatu tindakan tanpa ketergantungan dengan apapun. Kegiatan kemasyarakatan yang dilakukan oleh civil society dilakaun tidak dengan paksaan, akan tetapi secara sukarela. Ketaan terhadap norma dan nilai yang berlaku adalah ciri dari suatu komunitas yang sudah memahami penerapan konsep civil society.

Lebih lanjut, Ernest Gellner (1994) menjelaskan Adam Ferguson adalah tokoh yang pertama kali sudah menggunakan konsep civil society pada saat menyelesaikan tulisannya yang berjudul An Essay on the History of Civil Society. Ketika revoulsi industri dan berkembangnya kapitalisme sehingga menyebabkan terjadinya perbedaan yang cukup signifikan antara publik dan privat. Maka muncul ekonomi pasar yang menghilangkan tanggungjawab publik terhadap warga dikarenakan motivasi oleh keinginan agar mencapai perasaan puas terhadap kepentingan pribadinya saja. Kehadirana civil society diharapkan menjadi penghambar bagi negara tiran.

Sementara itu, civil society tidak dapat dipisahkan dari kekuasaan yang ada sebab terdapat tiga prinsip yang dapat menggerakan dan menghegemoni kehidupan masyarakat. Negara mempunyai kekuatan politik melalui regulasi dan intervensi, pasar memiliki kekuatan ekonomi melalui para pemodal atau investor atau tangantangan tersembunyi, sedangkan civil society memiliki kekuatan sosial melalui social movement atau gerakan sosial. Agar memahami konsep gerakan sosial lebih mudah lagi, berikut ini beberapa pemikiran sosiologi diantaranya sebagai berikut:

1. James M. Henselin (2008)

Menurutnya gerakan sosial merupakan kuantitas besar yang terorganisir guna mempromosikan atau melawan perubahan.

2. Paul B.Horton dan Chester L. Hunt (1989)

Gerakan sosial memberikan batasan yaitu upaya bersama yang memiliki tujuan untuk menolak perubahan atau menunjangnya.

3. Kamanto Sunarto (2004)

Menurutnya gerakan sosial adalah upaya atau usaha kolektif yang bertujuan untuk mempertahankan ata mengubah masyarakat yang ada di dalamnya.

Sementara itu menurut studi Henselin (2008), dari berbagai literatur ditemukan bahwa terdapat beberapa tahapan dari gerakan sosial:

1. Tahap agitatif dan kerusuhan. Awalnya muncul dari kelompok orang yang merasa terganggu atau dirugikan oleh kondisi tertentu sehingga memiliki keinginan untuk mengubahnya. Akhirnya muncul sosok aktor pemimpin yang 
dapat merangkul kepentingan orang-orang dalam bentuk isu sehingga berhubungan dengan sebab ketergangguan tersebut. Mayoritas gerakan pada tahap ini selalu gagal mendapatkan dukungan. Selanjutnya kegiatannya yang singkat dfan gerakan mati secara bertahap.

2. Tahap memobilisasi sumber daya yang tersedia. Selanjutnya pada tahap ini harus mampu memobilisasi ketersediaan sumber daya misalnya dana, waktu, keahliah orang atau kelompok yang bertujuan untuk memperoleh perhatian massa dan media massa.

3. Tahap mengorganisir atau pengorganisasian. Kemudian setelah melewati tahapan sebelumnya, pada tahap ini adanya pembagian kerja oleh pemimpin sehingga dapat memutuskan suatu kebijakan tertentu. Sementara itu struktur yang telah dibentuk diberikan tugas sehari-hari yang diperlukan guna kepentingan gerakan tetap berjalan dengan sebagai mana mestinya.

4. Tahap institusionalisasi. Ketika pada tahap ini, gerakan sudah berkembang menjadi gerakan suara birokrasi. Kontrol terdapat pada tangan pejabat yang akan mementingkan kepentingannya atau posisi mereka dari pada tujuan pergerakan organisasinya.

5. Tahap kehancuran atau kemungkinan bangkit kembali. Pada tahap terakhir ini terdapat perubahan kepentingan politik. Tidak ada lagi kelompok atau orang yang memiliki komitmen kuat dan tujuan bersama. Ketika saat redup seperti ini, akan ada kemungkinan lahir pemimpin yang lebih idealis dan miliki komitmen tinggi agar gerakan tetap berjalan seesuai dengan tujuan awal.

\section{Politik Lingkungan}

Menurut peterson mengemukakan bahwa politik lingkungan merupakan pendekatan yang mengkombinasikan permasalahan lingkungan, politik dan ekonomi guna merepresentasikan suatu perubahan yang dinamis antara manusia dengan lingkungan, dan antara kelompok yang beraneka ragam di masyarakat dalam skala dari individu lokal terhadap transnasional secara holistik (keseluruhan). (Hidayat, Herman, 2011). Sementara itu, politik lingkungan yang didefinisikan ilmuan lain ialah suatu pandangan untuk memahami hubungan yang kompleks antara masyarakat lokal, nasional, politik ekonomi global dan lingkungannya. Politik lingkungan juga diartikan sebagai upaya guna memahami keadaan politik, kondisi dan menjadikannya suatu jaringan dari perubahan atau pergantian lingkungan. Dewasa ini memahami politik lingkungan cenderung agar melihat lebih dalam dinamika atau perubahan lingkungan dan fokus atas suatu tatanan sistem manusia itu sendiri.

Sementar itu, Abe Kenichi mengartikan politik lingkungan adaluntun ah pandangan menganalisis permasalahan sumber daya alam dan faktor sebab-akibat kerusakan lingkungan secara poltik dan ekonomi guna memperoleh studi akademik yang sifatnya praktis. Politik lingkungan dalam definisi lainnya ialah kepedulian terhadap dimensi politik dalam penggunaan dan pemanfaatan sumber daya alam yang tersedia. Maka dari itu, jelas sudah bahwa area lingkup politik lingkungan 
merujuk sebagai metode analisis pada disiplin ilmu pengetahuan yang menyatu, biasanya divariasikan oleh rangkuman serta gagasan yang berhubungan dengan teori. (Herman, Hidayat, 2011).

Kemudian pada istilah ekologi politik secara etimologis berasal dari kata, yaitu ekologi dan politik. Fokus pengertian ekologi disini konteksnya pada sumber daya alam. Dapat diartikan membahas ekologi berarti mengkaji tentang sumber daya alam. Pada konteks ini pengertian politik diartikan sebagai kekuasaan. Maka dari itu, ekologi politik memfokuskan persoalan sumber daya alam sebagai permasalahan sosial-politik. Selaras dengan definisi tersebut, Bryant dan Bailey mengemukakan ekologi politik berfokus terhadap usaha untuk mempelajari sumber, kondisi, dan implikasi politik terhadap perubahan lingkungan hidup. Pendapat Bryant tentang ekologi politik adalah perubahan lingkungan sifatnya tidak netral, akan tetapi suatu bentuk politik lingkungan yang banyak melibatkan aktor yang memiliki kepentingan baik ditingkat lokal, nasional ataupun global. Politik lingkungan hidup adalah kajian yang mempelajari interaksi antara berbagai lapisan elemen sistem pada proses perumusan dan pengambilan keputusan terhadap kebijakan publik dalam menyelesaikan permasalahan lingkungan. Secara keseluruhan pembahasan berbagai isu krisis lingkungan, ideologi politik lingkungan, gerakan lingkungan, partai politik, sistem politik dan lingkungan serta proses politik lingkungan. Jelasnya, politk lingkungan hidup meminjam istilah Bryant dan Bailey yang diartikan sebagai bidang kajian dalam ilmu politik terhadap permasalahan lingkungan saat ini.

Sementara itu, politik lingkungan merupakan suatu metode terapan yang oleh parah ahli lingkungan digunakan untuk menganalisis kebijakan mengenai permasalahan lingkungan yang sesuai, biasa disebut dengan kontekstualisasi yang maju. Pendekatan tersebut memulai dengan aktor, dalam konteks ini pengguna sumber daya alam yang langsung dan memperhatikan beberapa hal yang mereka perbuat atau tidak dilakukan untuk menjelaskan kepada masyrakat mengapa menggunakan lingkungan dengan metode khusus, terkadang menyebabkan sumber daya rusak atau berkurang sehingga membahayakan lingkungan dan masyarakat sekitarnya. (Herman, Hidayat, 2011).

\section{Metodologi Penelitian}

Menurut Maleong (2007) mengemukakan metodologi kualitatif adalah metode penelitian yang menghasilkan deskripsi berupa kata-kata tertulis atau lisan dari orangorang dan perilaku yang telah diamati. Metode ini ditunjukan pada latar belakang individu itu sendiri secara keseluruhan. Pada penelitian kali ini, peneliti menggunakan metode kualitatif.

Sedangkan menurut Nasution (2003) penelitian kualitatif adalah mengamati orang dalam lingkungan, berinteraksi dengan mereka dan menafsirkan pendapat mereka tentang dunia sekitar, kemudian Sukmadinata (2005) menyatakan bahwa penelitian kualitatif adalah suatu penelitian yang ditujukan untuk mendeskripsikan dan 
menganalsis fenomena, peristiwa, aktifitas sosial, sikap, kepercayaan, presepsi, pemikiran orang secara individu maupun kelompok.

Kemudian Sayekti Pujosuwarno (1986) mengemukakan pendapat dari Moh. Surya dan Dumhur yang menjelaskan bahwa studi kasus dapat diartikan sebagai suatu teknik mempelajari seseorang individu secara mendalam untuk membantunya memperoleh penyesuaian diri. Menurut Lincoln dan Guba (Dedy Mulyana, 2004) penggunaan studi kasus sebagai suatu metode penelitian kualitatif memiliki beberapa keuntungan yaitu:

1. Studi kasus dapat menyajikan pandangan dari subjek yang nantinya diteliti

2. Studi kasus menyajikan penjelasan yang menyeluruh yang mirip dengan pengalaman pembaca di kehidupan sehari-hari

3. Studi kasus merupakan cara efektif untuk menunjukan hubungan antara peneliti dan responden

4. Studi kasus dapat memberikan uraian yang mendalam yang diperlukan bagi penliaian.

\section{Hasil dan Diskusi}

Earth Hour sudah menjadi sebuah gerakan cukup terkenal di Indonesia, dengan berbagai macam kegiatan kegiatan yang dilakukannya mampu menarik banyak masyarakat yang ingin berpartisipasi dalam gerakan menjaga lingkungan ini. Dalam melaksanakan program programnya, Earth Hour selalu memiliki target yang strategis seperti Earth Hour Tangerang. Target atau sasaran yang akan dituju oleh EHT setiap tahunnya adalah Walikota, Bupati dan juga dinas Lingkungan Hidup yang berada di Kota Tangerang, Kota Tangerang Selatan, dan juga Kabupaten Tangerang melalui edaran surat dan juga diskusi diskusi.

Pentingnya memiliki target untuk melaksanakan kegiatan sangat dirasakan oleh pengurus Eath Hour Tangerang. Dengan kesadaran bahwa seuah perubahan akan lebih mudah dilakukan jika pemimpinnya bergerak terlebih dahulu untuk memberikan contoh ataupun kesan pertama kepada masyarakatnya. Seperti yang dikatakan oleh Peterson yang mengatakan dalam politik lingkungan, factor politik ekonomi akan tercakup dalam politik lingkunan. Pendekatan yang dilakukan EHT teerhadap pemerintah, swasta dan juga masyarakat dinilai sangat baik mengingat hal - hal ini yang akan dilakukan oleh pemerintah Tangerang raya dimasa depan. Tangerang Raya seperti Tangerang Selatan dan juga Kota Tangerang, dalam beberapa tahun ini dan beberapa tahun kedepan sudah merencanakan banyak program dimana isu lingkungan menjadi salah satu program terbesarnya. Earth Hour Tangerang memiliki peran sebagai perantara dari pihak pemerintah terhadap pihak swasta dan masyarakat, pihak swasta kepada masyarakat, dan juga masyarakat kepada swasta dan pemerintah.

\section{Earth Hour Tangerang}

Earth Hour merupakan organisasi cabang dari organisasi dunia WWF ( World Wide Fund for Nature) yang merupakan induk dari organisasi dunia tentang kepedulian terhadap sumber daya alam. Indonesia mengkonsumi listrik sebesar $23 \%$ 
terfokus di DKI Jakarta dan Tangerang. Earth Hour Tangerang adalah sebuah komunitas yang berperan aktif dalam mengajak masyarakat untuk memperhatikan perubahan iklim di Kota Tangerang.

Earth Hour adalah acara yang dalam pelaksanaannya membutuhkan banyak audience sehingga penting untuk dilakukan upaya-upaya persuasive untuk menunjukan bahwasannya kegiatan ini mudah untuk dilakukan, dan dalam pelaksanaannya memiliki karakteristik tertentu. Karakteristik yang dimiliki oleh kegiatan penyelamatan lingkungan dengan usaha penghematan energi ini adalah kegiatan pertama yang sifatnya bukalah seperti aksi demonstarsi atau yang sifatnya memperotes akan sesuatu yang merusak lingkungan, namun lebih kepada aksi damai pada lingkungan.

Organisasi ini mengajak masyarakat Kota Tangerang untuk sadar akan pentingnya energy dan juga perubahan iklim di dunia melalui kegiatan kegiatan yang mereka laksanakan. Earth Hour Tangerang sudah aktif berjalan selama 4 tahun lamanya. Earth Hour Tangerang sudah banyak melakukan kegiatan yang mampu mengajak pemerintah di wilayah Kota Tangerang, Kabupaten Tangerang, dan Kota Tanerang Selatan untuk turut andil dalam pelesarian lingkungan.

Switch Off menjadi salah satu program unggulan mereka dimana program ini mampu mengajak Kota Tangerang, Kota Tangerang Selatan dan Kabupaten tangerang masuk dan menjadi bagian daei gerakan ini. Gerakan ini memiliki sistem dimana orang orang yang berpartisipasi dalam kegiatan ini akan mematikan daya listrik ditempat mereka berada seperti dirumah dalam kurun aktu 60 menit atau satu jam lamanya. Switch Off menjadi program unggulan yang dimiliki oleh organisasi Earth Hour dimana gerakan ini akan dilakukan di akhir bulan maret dan dilakukan setiap tahunnya oleh Earth Hour Tangerang dengan menghubungi petinggi daerah dan juga mengadakan kegiatan amal dan pentas seni untuk menandai puncak perayaan gerakan Switch Off. Karena gerakan ini dilakukan setiap tahun oleh organisasi Earth Hour, setiap tahun semakin banyak pihak yang terlibat seperti Pemerintahan Kota Tangerang yang mematikan daya listrik untuk Landmark Kota Tangerang dan juga beberapa pusat perbelanjaan di tangerang.

Mengingat banyak wilayah di Tangerang yang mulai paham dan juga menindaklanjuti urgensi perlindungan iklim dan alam, selain untuk kepentingan masyarakat, EHT semakin sering bergerak dengan memberikan edukasi edukasi terhadap masyarakat. Dimulai dari pentingnya menjaga lingkungan dan juga bagaimana perubahan iklim itu terjadi di sekolah sekolah yang ada di Tangerang Raya. Selain itu , kampanye seringkali dilakukan pada saat acara - acara besar dilaksanakan di Tangerang Raya, contohnya disaat ada penyelenggaraan Putra - Putri daerah, EHT akan menjadi salah satu pemberi materi dan juga pemberi bantuan dalam acara tersebut. Pendekatan pendekatan tersebut termasuk pendekatan yang cukup staregis karena mampu melibatkan banyak orang sekaligus dalam memberikan arahan mengenai cara cara dan juga pencegahan perubahan iklim yang lebih serius lagi.

Selain itu kegiatan mengedukasi masyarakat merupakan fokus utama dari kegiatan Earth Hour ini, dimana hal pertama yang harus dilakukan guna mengubah gaya hidup masyarakat menjadi peduli lingkungan yaitu tindakan mengedukasi akan 
pentingnya lingkungan itu sendiri. Contoh kegiatan nyata yaitu aksi EH Goes to School dimana Earth Hour Tangerang mendatangi beberapa sekolah untuk mengenalkan pentingnya peduli lingkungan. Lalu ada aksi rampok sampah plastik secara langsung dipusat-pusat perbelanjaan yang pastinya banyak menggunakan plastik sekali pakai, lalu Earth Hour menukarnya dengan membagikan tote bag sebagai pengganti kantong plastik sekali pakai.

Pada studi kasus gerakan Earth Hour Tangerang, khususnya dimana komunitas ini hendak memberi pemahaman bahwa perubahan kebiasaan tidak bisa diraih hanya dengan proses edukasi yang dilakukan satu kali selama satu jam setiap tahum, lebih dari itu peduli lingkungan harus dilakukan setiap hari dan diikuti oleh banyak pihak. Earth Hour bukan peristiwa seremonial, namun momentum yang mengingatkan diri sendiri untuk perubahan kecil yang berdampak besar bila menjadi gaya hidup. Dalam menggalang dukungan untuk kampanye hemat energi, Earth Hour Tangerang sejak tahun 2012 hingga sekarang melakukan pendekatan secara pemerintahan, korporat, media, masyarakat dan komunitas. Pendekatan ini ini dilakukan sebagai salah satu cara meraih dukungan secara penuh dalam setiap kegiatan yang dilakukan. Dukungan tersebut menjadi modal dasar Earth Hour Tangerang sebagai environment movement change untuk Tangerang Raya.

Selain edukasi yang melibatkan pemerintah, swasta, media, masyarakat dan komunitas secara khusus, Earth Hour Tangerang banyak melakukan kegiatan yang berbentuk aksi secara langsung yaitu gerakan Switch Off yang menjadi gaung dalam gerakan Earth Hour Tangerang, penanaman hutan mangrove juga menadi salah satu aksi rutin Earth Hour Tangerang pada hari bumi dan dilakukan dengan instansi pemerintah terkait, pihak swasta dan juga masyarakat. Tujuan dari gerakan ini yakni memberikan kesempatan kepada semua orang untuk memberikan partisipasinya dalam menjaga ketahanan bumi dan juga untuk mengajarkan bagaimana bumi akan terus terjaga kekuatannya jika kita terus membantunya untuk bertahan. Dengan menanam pohon mangrove di tepi pantai, kegiatan ini akan terus menjadi kegiatan rutinan yang positive dalam menjaga hubungan antara tiga lapisan penting di Tangerang maupun Indonesia.

Selain gerakan penanaman pohon mangrove, gaung gerakan Earth Hour Tangerang maupun Indonesia adalah gerakan switch off. Gerakan Switch off adalah gerakan yang memfokuskan pada gerakan pengehmatan listrik. Gerakan penghematan listrik ini dilakukan pada tanggal 22 Maret setiap tahunnya atau di minggu terakhir di bulan Maret. Akhir bulan Maret merupakan waktu dimana suhu bumi berada di titik terpanasnya sehingga membuat kondisi bumi akan butuk dietiap tahunnya jika kita yang menempati bumi tidak menjaganya. Maka gerakan mematikan listrik selama 60 menit diyakini akan membantu bumi agar tidak mencapai titik sangat panas. Sehingga perubahan iklim tidak terjadi begitu seignifikan. Gerakan switch off ini tentu perlu memakan bayak massa. Dimana gerakan ini harus didasarkan dengan banyaknya orang yang merasa pemikiran ini benar adanya dan membantu gerakan ini seperti halnya prinsip gerakan sosial. 
Dalam proses kegiatan Switch Off di wilayah Tangerang, organisasi Earth Hour memiliki beberapa strategi yang dilakukan. Karena target yang diinginkan oleh Earth Hour Tangerang merupakan wilayah Kota Tangerang, Kota Tangerang Selatan dan Kabupaten Tangerang, organisasi tersebut melakukan penyebaran tim. Penyebaran tim merupakan strategi Earth Hour Tangerang dalam mengundang tiga wilayah di Tangerang Raya untuk turun dalam gerakan Switch Off. Dengan strategi yang dilakukan oleh Earth Hour Tangerang dan juga banyaknya relawan yang dikerahkan untuk program ini, diharapkan program ini mampu membawa dampak dan perubahan bagi wilayah Tangerang. Proses yang dilakukan dalam melaksanakan program ini memakan waktu tiga samapi empat bulan lamanya dan proses dimulai dari bulan Desember 2018.

Setiap bulan Maret merupakan waktu yang digunakan oleh EHT untuk program unggulan mereka. Karena hal tersebut, proses dimulai pada bulan Januari 2019 merupakan waktu EHT untuk menyebarkan surat. Gerakan Switch Off sendiri dianggap sebagai gerakan yang cukup penting di wilayah Tangerang dimana Kota Tangerang dan Kota Tangerang Selatan memang sedang giat untuk mencanangkan wilayah yang ramah lingkungan dan Smart City. Oleh sebab itu, EHT mampu melihat sebuah peluang dengan membuat sebuah acara mengenai isu lingkungan yang akan diterima oleh pemerintah di wilayah Tangerang. Selain itu, isu lingkungan menjadi sebuah isu yang cukup menarik dibahas dalam pemerintahan masa kini walaupun belum ada keseriusan yang terlihat baik dari masyarakat maupun pihak pemerintah untuk membuat kebijakan yang dikhususkan untuk menangani urgensi perubahan iklim. Namun, dengan mengangkat isu lingkungan dan ikut turut masuk dalam gerakan tersebut, wilayah tersebut juga akan membawa dampak yang baik juga kepada masyarakat di wilayah tersebut.

\section{Kesimpulan}

Dengan memberikan pengertian dan kepada pemerintah, pihak swasta, dan masyarakat Earth Hour Tangerang mampu menjadi sebuah gerakan yang memiliki dampak yang baik bagi wilayah Tangerang Raya. Dengan pendekatan yang strategis dan mampu merangkul pemerintah, korporat, masyarakat, dan juga komunitas lainnya, Earth Hour Tangerang sudah mampu mengangkat urgensi pentingnya pemeliharaan lingkungan dan juga isu lingkungan pada wilayah Tangerang Raya. Walaupun belum ada tindakan serius dalam kebijakan linkungan di wilayah Tangerang Raya, Earth Hour percaya bahwa akan ada banyak perubahan yang terus terjadi jika dalam kebijakan terkait isu lingkungan di Tangerang Raya.

\section{Tentang Penulis}

Ilham Rasyid merupakan mahasiswa di ilmu pemerintahan Universitas Sultan Ageng Tirtayasa. Dengan peminatan penulis kepada kajian politik lingkungan, membuat penulis mencoba mengelaborasi terhadap isu-isu dalam politik lingkungan. 
Jessica Roma Felixiani Keviola merupakan mahasiswa di ilmu pemerintahan Universitas Sultan Ageng Tirtayasa. Dengan peminatan penulis kepada kajian politik lingkungan, membuat penulis mencoba mengelaborasi terhadap isu-isu dalam politik lingkungan.

\section{Ucapan Terimakasih}

Penulis mengucapkan terimaksih kepada dosen-dosen pembimbing di ilmu pemerintahan Universitas Sultan Ageng Tirtayasa. Terimakasih juga kepada semua phak yang telah membantu dan membuat penelitian ini menjadi sebuah artikel yang baik untuk dapat di terbitkan.

\section{Referensi}

Anita Nur Lailia. Agustus-Desember 2014. Gerakan Masyarakat Dalam Pelestarian Lingkungan Hidup (Studi Tentang Upaya Mencpitakan Kampung Hijau Di Kelurahan Gundih Surabaya). Jurnal Politik Muda, Vol. 3 No. 3. Diakses tanggal 9 Februari 2020.

Basrowi \& Suwandi. 2008. Memahami penelitian kualitatif. Jakarta: Rineka Cipta.

Dyer Hugh. (2018). Introducing Green Theory in International Relations. E-International Relation Students, 1-4. http://www.e-ir.info/2018/01/07/green-theory-ininternational-relations/ diakses pada tanggal 11 Februari 2020 pukul 09.10 WIB

John W. Creswell. 2009. Research Design Pendektana Kualitatif Kuantitatif, dan Mixed (California: SAGE Publications)

Kampanye Lingkungan. Bogor: Departement Sains Komu-nikasi dan Pengembangan Masyarakat Fakultas Ekologi Manusia Institut Pertanian Bogor.

Lay, C. (2007). Nilai Strategis Isu Lingkungan dalam Politik Indonesia. Jurnal Ilmu Sosial Dan Ilmu Politik, 11(2), 153-171.

Lee, S., Hahn, C., Rhee, M., Oh, J. E., Song, J., Chen, Y., Lu, G., Perdana, \& Fallis, A. . (2012). Permasalahan lingkungan di Kenya. Journal of Chemical Information and Modeling, 53(9), 1689-1699. https:// doi.org/10.1017/CBO9781107415324.004

Maxime C. van der Laarse. 2016. ENVIRONMENTALISM IN INDONESIA. Tesis Leiden University. Diakses pada tanggal 9 Februari 2020

Moleong, Lexy J. 2010. Metode Penelitian Kualitatif. Bandung: Remaja Rosdakarya.

Mulyana Dedi. 2001. Metodelogi Penelitian. Bandung: Remaja Rosda Karya.

Seftyono, C. (2014). Rawa Pening Dalam Perspektif Politik Lingkungan: Sebuah Kajian Awal. Indonesian Journal of Conservation, 3(1), 7-15.

Suharko, -. (2006). Gerakan Sosial Baru di Indonesia: Repertoar Gerakan Petani. Jurnal 
Volume 2, Issue 2, August 2020

http://hk-publishing.id/ijd-demos

Ilmu Sosial Dan Ilmu Politik, 10(1), 1-34. https:// doi.org/10.22146/JSP.11020

Ulfa, Ghina Shabrina. 2017. Efektivi-tas Instagram Earth Hour Bogor Sebagai Media

Wahyudin, E. A. (2018). GERAKAN SOSIAL BARU DAN POLITIK LINGKUNGAN (Studi Atas Kontribusi WALHI Terhadap Ruang Terbuka Hijau di DKI Jakarta 20042017). 